\title{
Review: Travels through the Western Borderlands of China
}

\section{Author(s): E. C. Wilton}

Review by: E. C. Wilton

Source: The Geographical Journal, Vol. 39, No. 3 (Mar., 1912), pp. 268-270

Published by: geographicalj

Stable URL: http://www.jstor.org/stable/1778443

Accessed: 19-06-2016 09:11 UTC

Your use of the JSTOR archive indicates your acceptance of the Terms \& Conditions of Use, available at

http://about.jstor.org/terms

JSTOR is a not-for-profit service that helps scholars, researchers, and students discover, use, and build upon a wide range of content in a trusted digital archive. We use information technology and tools to increase productivity and facilitate new forms of scholarship. For more information about JSTOR, please contact support@jstor.org.

The Royal Geographical Society (with the Institute of British Geographers), Wiley are collaborating with JSTOR to digitize, preserve and extend access to The Geographical Journal 
geographers have concluded from the reports of other travellers; but if $\mathrm{Mr}$ Bury was really told by his guides that the land strip south of Behanal-Jezab is a tongue of the main waste, and if he is not using the name Rubaal-Khali loosely to include any outlying desert area met with towards the fringe of the Red desert itself, the maps must be corrected.

Altogether a curious book by a curious man, of whose singular qualifications for advancing knowledge of Southern Arabia it ought to be possible to make further use, as General Maitland indeed urges in his preface. The Royal Geographical Society has tried to avail itself of his services, but the attempt ended in a miscarriage, the responsibility for which is not easy to assign. $\mathrm{He}$ is well known also both to the War Office and the Indian Government, and he is still quite young.

D. G. H.

\section{Travels throdgh the Western Borderlands of China.}

'Les Derniers Barbares' (China, Tibet, Mongolie). Par le Commandant d'Ollone. Paris: Pierre Lafitte. 1911. $15 \mathrm{fr}$.

In this volume Major d'Ollone gives a general description of the journey in China, Tibet, and Mongolia, made by himself and his three companionsCaptain de Fleurelle, Captain Lepage, and Lieutenant de Boyve-in 1907-1908, to which frequent reference has been made in the Journal. After two months spent in ethnographical work in Cambodia, Cochin-China, Tongking, and on the frontiers of the Chinese province of Kwangtung, the party proceeded to Yunnan-fu, where, on April 15, 1907, the journey as recorded in this volume was begun.

This journey may be conveniently divided into three parts: (1) a passage across the northern portion of the independent Lolo country on the left bank of the Yangtse, followed by a visit to the Lolos on the right bank in the northeast of Yunnan. This stage was undertaken by Major d'Ollone and Lieutenant de Boyve, accompanied, during the first part, by Père de Guébriant, well known for his knowledge of and success in dealing with the Lolos; (2) travel in country inhabited principally by Miao tribes in the east of Yunnan and west of Kweichau provinces. This was carried out by Captain de Fleurelle and Captain Lepage; (3) travel through the Chienchiang valley, northwards viâ Chengtu and Sungp'an into the lands of Sifans and nomad tribes of Tibet to Lhabrang monastery, thence to Lanchou and north-eastwards to Peking. The journey is illustrated by excellent photographs, and accompanied by four maps, three giving route sketches of the three stages, while the fourth is a general map of the whole journey.

Major d'Ollone supplies new and interesting details of the Spartan simplicity and rudeness of life of the Lolo chiefs, who owe their position entirely to personal vigour, prowess in warfare, and the resources of their particular clan or group of clans. War appears to be the end and aim of Lolo desire. These fierce and hardy mountaineers not only harass one another, but make constant raids upon neighbouring Chinese villages, whose inhabitants they not infrequently carry away as slaves. They despise agriculture and industrial arts, which are carried on by their serfs and slaves. They are fine horsemen, and their national arm is the lance, 15 to 20 feet long. Major d'Ollone appears to regard the north-east corner of Yunnan on the right bank of the Yangtse as "the cradle of the Lolo race," and considers them to be serious rivals of the Chinese in the impending struggle for the possession of the wild lands to the west. We may remark, however, that it is not improbable that this fine 
warlike race migrated from the region of the Tung-t'ing lakes in Honan, westwards through the north of the provinces of Kweichau and Yunnan, about the second century B.C., under Chinese pressure. At an earlier date, they may have come from the south of the Koko-nor into the province of Honan, and have been gradually forced southwards by the Chinese advance. The limits of space make it impossible to do more than refer thus inadequately to Major d'Ollone's graphic and sympathetic description of the independent Lolos.

At Suifu, on the Yangtse, the party met the French gunboat Olry, which a short time previously had successfully negotiated the dangerous rapids between that town and Pingshan, generally described as the navigable limit for junks on the Yangtse.**

The second stage of the journey-exploration work among the Miao-being accomplished, the two parties met again at Yunnan-fu for the final march northwards to Peking. This stage took the mission again in the direction of the rich and fertile Chienchiang valley, whose heights are still held by the Lolos in spite of Chinese endeavours to dislodge them. Mosso tribesmen were met, $\dagger$ and Major d'Ollone measured several individuals. He gives their stature as exceeding 6 feet 6 inches. Leaving Ningyuan-fu in the Chienchiang valley on December 28, 1907, the expedition proceeded to Tachienlu and Chengtu, and on April 24 a start was made from Sungp'an, the door into the Sifan country. Under the term Sifan (literally, western barbarian) Major d'Ollone points out that the Chinese mix up all peoples said to be of Tibetan stock in these regions. The area beyond Sungp'an is known as the Grass country. Six inches of snow commonly fell at night or in the early morning, but by 10 a.m. had disappeared, evaporated into the dry air and licked up by the wind. The sources of the Min river were noted at an elevation of 14,000 feet. The passage of the Tengona pass (14,000 feet) brought the travellers into the basin of the Yellow river. With the last glimpses of the mountains of China they arrived in the Dzorgue confederation of nomad tribes occupying the top of the loop of the Yellow river. Brigandage is rife here. The winter village of Pan-yu, at which the party halted, had been visited eight years before by the ill-fated expedition of Messrs. Watts-Jones and Grant Birch. Major d'Ollone gives valuable and interesting information on the Lamaist monasteries in this region. His party was coldly received by the lamas, and Captain Lepage and Lieut. de Boyve were actually attacked close to Lhabrang and narrowly escaped with their lives. On reaching Liangchou, where the expedition met M. Pelliot, the leader's three companions left for Taiyuan-fu and Peking by way of the Ordos country, while he himself, taking a more northerly route, pursued his Mohammedan researches. On arrival at the sacred mountain of Wutai he met the Dalai Lama, also on his way to Peking, and was received in audience by him.

To sum up, Major d'Ollone and his companions covered over 5000 miles, of which more than 1700 had not been traversed by Europeans. The mission brought back 2000 photographs of scenery and types of natives; over $200 \mathrm{com}$ pleted surveys; vocabularies of non-Chinese dialects, Lolo documents, and historical inscriptions in Chinese, Sansorit, Tibetan, Mongol, Manchu, Arabic, and Lolo ; besides a miscellaneous collection of arms, paintings, and coins. The scientific documents of the mission are to be contained in seven supplementary volumes-one of which, on the Chinese Mohammedans, has already appeared.

* Pingshan had been visited by the British gunboat Woodcock in 1904.

$\uparrow$ The Mossos generally are to be found more to the west, and Tibetan chronicles state that the Mossos were conquered and driven back to the south-east. 
It has been here possible to give only a brief outline of Major d'Ollone's valuable and interesting work. The courage, determination, and endurance of himself and his companions are worthy of the highest admiration.

\section{E. C. WiLton.}

'Turkestan.' By W. E. Curtis. (London: Hodder \& Stoughton. 1911.

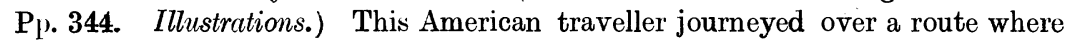
permission to do so is not easily come by - the Central Asian railway. His visits to Merv, Bokhara, and Samarkand resulted in some study and good photographs of the political and economic conditions and the remains of antiquity in those cities, and he kept an observant eye on all that was to be seen from the window of his railway carriage and during his travels by other means of conveyance. We find a well-judged appreciation of Russian methods of administration in these territories, of which the writer has also studied the history. He appears to omit certain non-political considerations from his conception of a railway linking the Russian and British Indian systems through Afghanistan.

'Through India and Burma with Pen and Brush.' By A. Hugh Fisher. (London: Laurie. [N.d.] Pp. xiii., 358. Illustrations. 15s. net.) We prefer the products of the author's pen to those of his brush, for the coloured illustrations form some of the least successful examples of the three-colour process, with the exception of one or two which are admirable. The text is largely narrative, is easily readable, and affords a considerable amount of miscellaneous information which may be useful to travellers on Mr. Fisher's route. It may be added that he travelled in the East as artist for the Visual Instruction Committee of the Colonial Office.

'Across China on Foot.' By E. J. Dingle. (Bristol: Arrowsmith. 1911. Pp. xvi., 446. Map and Illustrations. 16s.) Mr. Dingle, who has travelled widely in the East, deals in this volume with a series of journeys extending from Shanghai to Bhamo, by way of the Yangtse-kiang and Tali-fu. So far as can be gathered from a rather indistinct map, he was in country previously unseen by a European in certain parts of Yunnan. But he carried no surveying instruments, nor was concerned directly with exploration, as his wish was rather to know something of Chinese political, social, and economic conditions from within. The book is therefore of special interest to students of these topics at the present time. But as far as concerns the less-known or unknown parts of his route there is little material of geographical service beyond a few photographs. Some of these are well-chosen views over wide areas.

'The Full Recognition of Japan.' By R. P. Porter. (London : Frowde. 1911. Pp. xii., 789. Maps and Illustrations. 10s. 6d.) The author has had two opportunities of visiting Japan in order to report for journalistic purposes on the economic conditions of the country. These visits took place at an interval of fourteen years, and the survey contained in the present volume is therefore of unusual interest, as such remarkable political and economic changes had taken place during the interval between the writer's visits. He covers not only Japan, but Korea, Formosa, and Manchuria. He surveys the history of the empire so far as it is necessary as an introduction to the present expansion. He has a chapter on the physical characteristics of the country, which, though short, appears to contain all essential facts, and he deals at length with every branch of administration, with economic products, with labour and commerce, and with art. The book should form a standard of reference on these topics, though on some of them it enters into such high detail that the rapid development of Japan will necessitate early revision. 